\title{
Testosterone levels in men with chronic obstructive pulmonary disease with or without glucocorticoid therapy
}

\author{
A. Kamischke*, D.E. Kemper**, M.A. Castel*, M. Lüthke**, C. Rolf*, \\ H.M. Behre*, H. Magnussen**, E. Nieschlag*
}

Testosterone levels in men with chronic obstructive pulmonary disease with or without glucocorticoid therapy. A. Kamischke, D.E. Kemper, M.A. Castel, M. Lüthke, C. Rolf, H.M. Behre, H. Magnussen, E. Nieschlag. (OERS Journals Ltd 1998.

ABSTRACT: Under the clinical impression that patients with chronic obstructive pulmonary disease (COPD) may demonstrate signs compatible with hypogonadism, we investigated whether oral glucocorticoid therapy is associated with testosterone deficiency.

Thirty six men with COPD of whom 16 were receiving oral glucocorticoid medication (mean \pm SEM dose $9.4 \pm 1.1 \mathrm{mg}$ prednisolone) were investigated in a cross-sectional cohort study.

Patients with or without oral glucocorticoid therapy were not different in terms of age, smoking history and additional therapy. Vital capacity, forced expiratory volume in one second, airway resistance, intrathoracic gas volume and blood gases at rest were not different between the groups. However, patients receiving glucocorticoids had a shorter $6 \mathrm{~min}$ walking distance (mean \pm SEM $205 \pm 27$ versus $288 \pm 26 \mathrm{~m} ; \mathrm{p}=0.02$ ) compared to patients without oral steroid therapy. Serum levels of testosterone $($ mean \pm SEM $13.7 \pm 0.9)$ were below normal $(<12 \mathrm{nM})$ in 15 of 36 patients. Serum testosterone did not correlate with any other evaluated parameter. Serum levels of free testosterone (free $T)($ mean \pm SEM $172.3 \pm 7.8 \mathrm{pM})$ were decreased in 25 of the 36 patients, including all patients receiving glucocorticoid treatment. In the 16 patients taking glucocorticoids free $T$ was correlated $(p=0.016)$ with the current glucocorticoid dosage $(r=-0.504 ; p=0.007)$ and the body mass index $(r=0.241 ; p=0.037)$. All other parameters examined revealed no significant correlations in multiple regression analysis.

Glucocorticoid treatment appears to aggravate hypogonadism and a therapeutic study using testosterone in patients with chronic obstructive pulmonary disease receiving glucocorticoid medication appears warranted.

Eur Respir J 1998; 11: 41-45.
*Institute of Reproductive Medicine of the University, D-48129 Münster, Germany and $* *$ Centre for Pneumology and Thoracic Surgery, D-22927 Großhansdorf, Germany.

Correspondence: E. Nieschlag

Institute of Reproductive Medicine of the University

Domagkstr. 11

D-48129 Münster

Germany

Fax: 00492518356093

Keywords: Ageing

chronic obstructive pulmonary disease

glucocorticoid treatment

hypogonadism

testosterone

Received: March 211997

Accepted after revision August 311997

This work was supported in part by the Bundesministerium für Gesundheit
Many chronic and/or severe diseases and a number of drugs are known to induce hypogonadism [1]. Patients with chronic obstructive pulmonary disease (COPD) may have symptoms compatible with hypogonadism and there is evidence that these patients have significant atrophy of Leydig cells $[2,3]$. This atrophy might be a consequence of hypoxic inhibition of pituitary gonadotropin secretion in patients with COPD [4].

In addition it seems likely that glucocorticoids can lower testosterone biosynthesis [5, 6] which is consistent with the decreased plasma testosterone levels found in men with Cushing's syndrome [7]. It has been shown that highdose prednisolone or dexamethasone treatment can reduce the normal nocturnal increase in testosterone [8]. Furthermore, it has been shown that glucocorticoids can diminish the maximal serum testosterone levels after human chorionic hormone (hCG) stimulation due to a reduction of essential adrenal precursors [9]. Moreover, prolonged prednisolone treatment affects the pituitary response to gonadotropin releasing hormone $(\mathrm{GnRH})$, resulting in dec- reased luteinizing hormone $(\mathrm{LH})$ secretion and low plasma testosterone [10].

Ageing leads to a decline in serum testosterone [11] and to a decreased testicular and pituitary maximal secretion after hCG and GnRH stimulation tests in men beyond the fourth decade of life [12]. Cross-sectional studies have shown an average decline in testosterone of $0.4 \% \cdot \mathrm{yr}^{-1}$ and an increase of sex hormone binding globulin (SHBG) of $1.2 \% \cdot \mathrm{yr}^{-1}$ between $39-70 \mathrm{yrs}$ of age [13]. However, the physiological decrease of testosterone with normal ageing never reaches the extent seen in clinically manifested hypogonadotrophic hypogonadism.

As we had the clinical impression that patients with COPD suffer from hypogonadism more often than other patients of comparable age, we investigated whether patients with severe COPD, with or without glucocorticoid treatment, have a testosterone deficiency. The findings suggest that testosterone therapy may be a rational approach in these patients. 


\section{Materials and methods}

\section{Study design and patients}

Thirty six patients (mean \pm SEM age $64.5 \pm 1.5$ yrs) with stable COPD were examined in a cross-sectional cohort study. Diagnosis and treatment of COPD followed international guidelines [15]. In addition, no patients had evidence of conditions that might interfere with exercise testing. The study protocol was approved by the Ethics Committee of the State Medical Board and written informed consent was obtained from each patient.

Clinical information is given in table 1. Almost all patients were receiving a combination of inhaled and oral therapy. At the time of examination, 16 patients had been

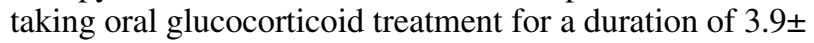
0.4 yrs. There were no significant differences between control and glucocorticoid-treated patients in the other types of drugs being used.

In addition to a medical history and routine clinical investigation of lung function, smoking, drugs and other diseases, a thorough andrological history was taken including the use of standardized diaries [16]. In addition, physical and sonographic evaluation of scrotal contents were performed.

\section{Lung function testing and blood gas analysis}

Forced expiratory volume in one second, vital capacity, airway resistance, intrathoracic gas volume and residual volume were measured by whole body plethysmography (Masterlab, Jaeger, Würzburg, Germany). The transfer factor of the lung for carbon monoxide (TLCO) and the TL,CO divided by alveolar volume (Krogh factor) were determined by the single breath method. The TL,CO was corrected for the concentration of haemoglobin [17]. Predicted values were calculated according to European guidelines [15]. Blood gas analyses (Blood Gas Analyzer model 278; Ciba-Corning, Fernwald, Germany) were determined from the hyperaemic ear lobe to give $\mathrm{pH}$ and

Table 1. - Baseline characteristics of male patients with chronic obstructive pulmonary disease

\begin{tabular}{|c|c|c|}
\hline Medication & $\begin{array}{l}\text { Patients } \\
\text { receiving oral } \\
\text { prednisolone } \\
\text { therapy }\end{array}$ & $\begin{array}{l}\text { Patients not } \\
\text { receiving oral } \\
\text { prednisolone } \\
\text { therapy }\end{array}$ \\
\hline Patients $\mathrm{n}$ & 16 & 20 \\
\hline Age yrs & $65.5 \pm 2$ & $63.8 \pm 2.2$ \\
\hline Weight $\mathrm{kg}$ & $77.8 \pm 3.3$ & $86.6 \pm 4.5$ \\
\hline Height $\mathrm{cm}$ & $176.2 \pm 1.7$ & $177.8 \pm 1.7$ \\
\hline Body mass index $\mathrm{kg} \cdot \mathrm{m}^{-2}$ & $25.1 \pm 1.1$ & $27.2 \pm 1.2$ \\
\hline Baseline Dyspnoea Index score & $6.1 \pm 0.5$ & $6.7 \pm 0.8$ \\
\hline $\begin{array}{l}\text { Systemic glucocorticoid } \\
\text { dose } \mathrm{mg} \cdot \mathrm{day}^{-1}\end{array}$ & $9.4 \pm 1.1$ & 0 \\
\hline Patients receiving & & \\
\hline Theophylline $\mathrm{n}$ & 14 & 12 \\
\hline Inhaled corticoid aerosol $\mathrm{n}$ & 13 & 12 \\
\hline Inhaled $\beta_{2}$-agonist aerosol $\mathrm{n}$ & 13 & 11 \\
\hline Inhaled anticholinergic aerosol $\mathrm{n}$ & 9 & 6 \\
\hline Oxygen supplementation $\mathrm{n}$ & 2 & 0 \\
\hline Smoking pack-years & $58.3 \pm 8.2$ & $54.6 \pm 6.4$ \\
\hline
\end{tabular}

arterial partial pressures of carbon dioxide and oxygen. A clinical dyspnoea rating [18] was assessed using the German translation of the Baseline Dyspnoea Index (BDI) [19].

\section{Exercise testing}

Exercise performance was assessed as the 6 min walking distance (6MWD) in a self-paced treadmill walking test (LE 2000; Jaeger, Würzburg, Germany) on a horizontal treadmill [20].

\section{Hormone measurements}

Blood samples were taken at 08:00 and 11:00 h. All measurements were performed within one assay. Serum levels of LH, follicle-stimulating hormone (FSH), SHBG, and prostate specific antigen (PSA) were determined by highly specific time resolved fluoroimmunoassays (DELFIA; Pharmacia GmbH, Freiburg, Germany). The intraassay coefficients of variation were: LH $2 \%$, FSH $1.4 \%$, SHBG $0.8 \%$ and PSA $2.5 \%$. The normal ranges in our laboratory are: LH 2-10 international units (IU) $\cdot \mathrm{L}^{-1}, \mathrm{FSH}$ 1-7 IU. $\mathrm{L}^{-1}$ and SHBG 11-71 nM. The upper normal limit for PSA is $4 \mu \mathrm{g} \cdot \mathrm{L}^{-1}$.

Testosterone was measured by radioimmunoassay (RIA), as previously described [21]. The intra-assay coefficient of variation was $5.3 \%$. Serum levels of free testosterone (free T) were determined after ultrafiltration by RIA [22]. The detection limit for free $\mathrm{T}$ was $50 \mathrm{pM}$. The intra-assay coefficient of variation for free $\mathrm{T}$ was $8.3 \%$. Oestradiol was measured by RIA (Sorin Biomedica, Saluggia, Italy). The intra-assay coefficient of variation for oestradiol was 5.8\%. Normal values in our laboratory for testosterone are greater than $12 \mathrm{nM}$, the upper normal limit for oestradiol is 250 $\mathrm{pM}$. The normal values for serum free $\mathrm{T}$ are greater than $200 \mathrm{pM}[23]$.

\section{Statistical analysis}

All variables were checked for normal distribution using the Kolmogorov-Smirnov one-sample test for goodnessof-fit. When necessary, analysis was performed on logarithmically transformed data. Two-sided p-values of 0.05 or less were considered significant. Covariance was evaluated by multivariate general factorial analysis of variance. After variance analysis all variables were tested by stepwise linear multiple regression analysis. Differences between different groups of patients were tested by t-test for independent samples or Pearson's Chi-squared test. All analyses were performed using the statistical software SPSS for Windows version 6.1 (SPSS, Inc., Chicago, IL, USA). In general, results are given as mean \pm SEM.

\section{Results}

\section{Clinical and endocrine features}

Eighty four per cent of the patients reported concurrent diseases consisting mostly of cardiac and gastro-intestinal diseases. In no case was there any evidence of long-standing hypogonadism. No severe andrological illnesses or 


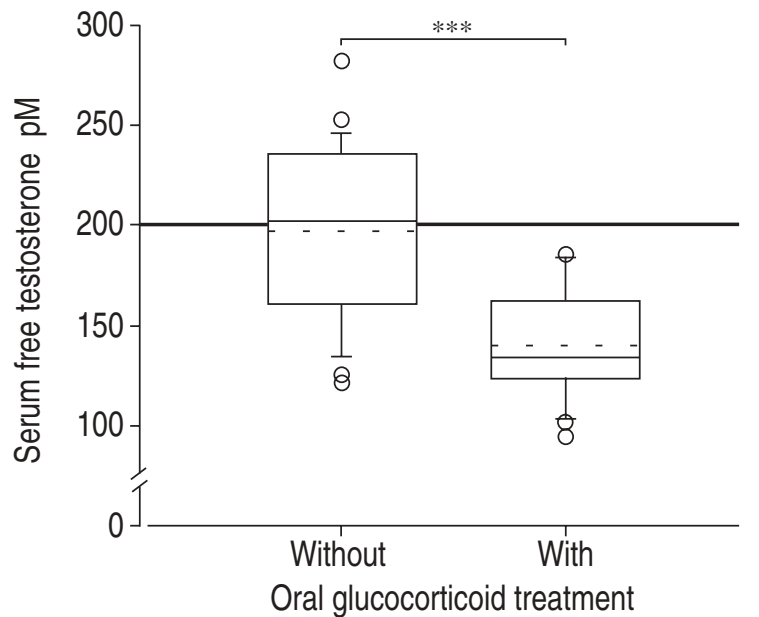

Fig. 1. - Plot of free testosterone values of 16 patients receiving oral glucocorticoid treatment compared to 20 patients not receiving oral glucocorticoid treatment. The box represents 25 th and 75 th percentiles respectively. Inner solid line shows the 50th percentile, inner broken line the mean. Capped bars outside reflect the 10th and 90th percentile respectively. In addition, data outside the 10th and 90th percentile are plotted as inidividual symbols. — : lower normal limit. $* * *: \mathrm{p}<0.001$.

injuries were reported except for benign prostatic hyperplasia for which surgery had been performed in five patients. PSA was elevated in nine patients up to a maximum of $26.3 \mu \mathrm{g} \cdot \mathrm{L}^{-1}$. Distribution of symptoms compatible with hypogonadism were similar in both groups and mainly consisted of loss of muscle strength $(n=28)$, skin symptoms $(n=18)$, and infrequent sex or an unsatisfactory sex life $(n=16)$.

Serum levels of testosterone (mean \pm SEM $13.7 \pm 0.9 \mathrm{nM}$ ) were decreased in 15 patients. In the analysis of variance only BMI $(\mathrm{r}=-0.16, \mathrm{p}=0.03)$ and oestradiol $(\mathrm{r}=0.09, \mathrm{p}=$ $0.024)$ levels correlated with testosterone, and these were no longer present after including SHBG in the variance analysis. Therefore, the variance analysis was continued only for biologically active free $\mathrm{T}$ values. Overall, serum levels of free $\mathrm{T}(172.3 \pm 7.8 \mathrm{pM})$ were below the lower normal range. In all patients taking oral glucocorticoids, decreased free $\mathrm{T}$ values were found (fig. 1), whereas only

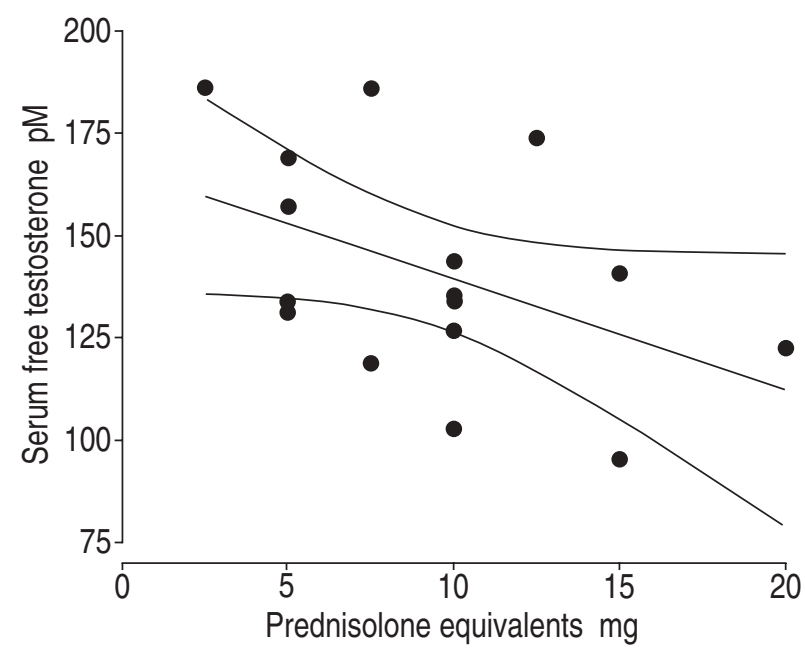

Fig. 2. - Daily oral glucocorticoid dose expressed as prednisolone equivalent versus serum free testosterone in 16 patients treated with prednisolone. The regression line and the $95 \%$ confidence limits are shown. $\mathrm{r}=-0.504 ; \mathrm{p}=0.007$.
$45 \%$ of the others had decreased free $\mathrm{T}$ levels. In patients receiving glucocorticoid medication free $\mathrm{T}$ was correlated $(\mathrm{p}=0.016)$ with the current glucocorticoid dosage $(\mathrm{r}=$ $-0.504 ; \mathrm{p}=0.007$; fig. 2$)$ and the BMI ( $\mathrm{r}=0.241 ; \mathrm{p}=0.037)$. For further details see table 2 .

Lung function testing, blood gas analysis and exercise testing

Results of lung function testing, blood gas analysis and exercise testing are given in table 3. Walking distances were significantly decreased in patients receiving oral glucocorticoids compared to those without. All other evaluated indices of lung function, blood gas and exercise testing were not different between the two groups.

Table 2. - Hormone measurements in 16 chronic obstructive pulmonary disease patients treated with prednisolone and 20 patients not receiving prednisolone therapy

\begin{tabular}{|c|c|c|}
\hline & $\begin{array}{c}\text { Patients } \\
\text { receiving } \\
\text { oral } \\
\text { prednisolone } \\
\text { therapy } \\
n=16\end{array}$ & $\begin{array}{c}\text { Patients not } \\
\text { receiving } \\
\text { oral } \\
\text { prednisolone } \\
\text { therapy } \\
n=20\end{array}$ \\
\hline Luteinizing hormone IU.L-1 & $3.4 \pm 0.3$ & $4.1 \pm 0.7$ \\
\hline $\begin{array}{l}\text { Follicle stimulating } \\
\text { hormone IU } \cdot \mathrm{L}^{-1}\end{array}$ & $7.3 \pm 1 *$ & $4.8 \pm 0.7$ \\
\hline Testosterone nM & $12.1 \pm 1.3$ & $15.1 \pm 1.2$ \\
\hline $\begin{array}{l}\text { Patients with } \\
\quad \text { testosterone }<12 \mathrm{nM} \mathrm{n}\end{array}$ & 9 & 6 \\
\hline $\begin{array}{l}\text { Sex hormones binding } \\
\text { globulin } \mathrm{nM}\end{array}$ & $47.6 \pm 6.2$ & $61.3 \pm 5.3$ \\
\hline Free testosterone $\mathrm{pM}$ & $141.2 \pm 6.7 *$ & $197.15 \pm 10$ \\
\hline $\begin{array}{l}\text { Patients with free testosterone } \\
<200 \mathrm{pM} \mathrm{n}\end{array}$ & $16^{*}$ & 9 \\
\hline Oestradiol pM & $60.4 \pm 3.4$ & $73.5 \pm 5.3$ \\
\hline $\begin{array}{l}\text { Prostate specific } \\
\text { antigen } \mu \mathrm{g} \cdot \mathrm{L}^{-1}\end{array}$ & $5.06 \pm 1.7$ & $2.52 \pm 0.2$ \\
\hline
\end{tabular}

Table 3. - Lung function, blood gas and exercise testing parameters in patients with chronic obstructive pulmonary disease

\begin{tabular}{|c|c|c|}
\hline Evaluated parameter & $\begin{array}{c}\text { Patients } \\
\text { receiving } \\
\text { prednisolone } \\
\text { therapy } \\
n=16\end{array}$ & $\begin{array}{c}\text { Patients not } \\
\text { receiving } \\
\text { prednisolone } \\
\text { therapy } \\
\mathrm{n}=20\end{array}$ \\
\hline $\mathrm{VC} \%$ pred & $73.3 \pm 4.4$ & $68.2 \pm 3.5$ \\
\hline $\mathrm{FEV}_{1} \%$ pred & $33.4 \pm 4.7$ & $39.8 \pm 3.6$ \\
\hline IGV $\%$ pred & $205 \pm 19.2$ & $160.4 \pm 10.6$ \\
\hline$R$ aw $\mathrm{kPa} \cdot \mathrm{L}^{-1} \cdot \mathrm{s}^{-1}$ & $0.43 \pm 0.05$ & $0.39 \pm 0.05$ \\
\hline$T \mathrm{~L}, \mathrm{CO} \%$ pred & $77.5 \pm 6.8$ & $83.7 \pm 5.6$ \\
\hline$P \mathrm{a}, \mathrm{O}_{2}$ at rest $\mathrm{kPa}$ & $9.12 \pm 0.44$ & $9.12 \pm 0.24$ \\
\hline$P \mathrm{a}, \mathrm{CO}_{2}$ at rest $\mathrm{kPa}$ & $4.88 \pm 0.21$ & $5.01 \pm 0.16$ \\
\hline 6MWD & $205.1 \pm 26.7 *$ & $287.5 \pm 25.5$ \\
\hline
\end{tabular}

Values are presented as mean \pm SEM. VC: vital capacity; FEV1: forced expiratory volume in one second; IGV: intrathoracic gas volume; Raw: airway resistance; TL,CO: transfer factor for carbon monoxide; $P \mathrm{a}, \mathrm{O}_{2}$ : arterial partial pressure of oxygen; $P_{\mathrm{a}, \mathrm{CO}_{2}}$ : arterial partial pressure; 6MWD: 6 min walking distance; $\%$ pred: percentage of predicted value. *: difference between groups pð0.05. 


\section{Discussion}

We investigated patients with severe COPD with or without glucocorticoid treatment. The groups were not different in terms of clinical features, smoking habits and most of the lung function indices measured at rest (table 1). However, walking distances were shorter in patients with oral glucocorticoids compared to those without. Shorter walking distance may be compatible with the hypothesis stating that oral glucocorticoids contribute to respiratory muscle weakness in COPD patients [24].

Similarly, the muscle weakness observed in patients treated with glucocorticoid might have been a consequence of the significantly reduced (fig. 1) free $\mathrm{T}$ values that we and others [25] found in comparison to COPD patients without glucocorticoid therapy. Free $\mathrm{T}$ values were significantly correlated with the current glucocorticoid do-sage (fig. 2). Possible reasons for the observed hypogona-dism may be glucocorticoid-induced suppression of the adrenals [9], a direct inhibitory effect via testicular glucocorticoid receptors [5] or decreased testosterone biosynthesis via reduced content of LH receptors in Leydig cells [6].

Another possible reason for the hypogonadism might be hypoxic inhibition of $\mathrm{LH}$ secretion $[4,26]$ due to the COPD together with an exaggerated effect of the general mild decrease in testosterone during ageing [11, 13]. Although single time point LH analysis may be misleading because of its pulsatility, only five of the present patients showed subnormal serum $\mathrm{LH}$ as a possible result of inhibition of pituitary LH secretion resulting in secondary hypogonadism with subnormal testosterone values (range 8.4-10.3 nM). On the other hand, elevation of LH, which would be expected with low testosterone levels, was not seen in either group, and no correlation was found between gonadotrophins and lung function. Although we cannot exclude partial inhibition of pituitary LH secretion, we agree with others $[1,25,27]$ that COPD alone is not likely to be the primary cause of the observed hypogonadism. An effect of ageing on testosterone levels was not observed in this study; this otherwise minor effect is probably outweighed by additional medication and illnesses which are known to decrease testosterone values [13, 14]. However, nine out of 20 patients with COPD not receiving glucocorticoid medication also had decreased free $\mathrm{T}$ levels. The aetiology is likely to be multifactorial, but, as all patients receiving glucocorticoid treatment had decreased free $\mathrm{T}$ levels, it is clear that the glucocorticoid medication appears to aggravate hypogonadism. Therefore, in this study other possible contributory factors such as COPD, ageing, other intercurrent illnesses and medication appeared to be less important than glucocorticoid treatment and were not consistent within the patient group without oral glucocorticoids.

It has previously been demonstrated that testosterone antagonizes the deleterious effects of cortisone on diaphragmatic endurance in rats [28] and has a clear anabolic effect on muscle size and strength in normal human males [29]. In addition, in patients with chronic obstructive pulmonary disease, anabolic steroids have been shown to increase respiratory muscle mass and strength [30]. Other studies have shown that testosterone reverses the deleterious effects of glucocorticoid drugs on bone density and soft tissues in asthmatic males [31]. To clarify whet- her testosterone/might have a beneficial influence on lung function in patients with chronic obstructive pulmonary disease receiving oral glucocorticoid treatment, a controlled clinical trial appears warranted.

Acknowledgements: The authors wish to thank K. Brunswicker, M. Niemeier and E. Pekel for their technical assistance and S. Nieschlag for language editing.

\section{References}

1. Handelsman DJ. Testicular dysfunction in systemic diseases. In: Nieschlag E, Behre HM, eds. Andrology: Male Reproductive Health and Dysfunction. Heidelberg, Springer, 1997; p. 227.

2. Gosney JR. Effects of hypobaric hypoxia on the Leydig cell population of the testis of the rat. J Endocrinol 1984; 103: 59-62.

3. Gosney JR. Atrophy of Leydig cells in the testis of men with longstanding chronic bronchitis and emphysema. Thorax 1987; 42: 615-619.

4. Semple d'A, Beastall GH, Watson WS, Hume R. Hypothalamic-pituitary dysfunction in respiratory hypoxia. Tho$\operatorname{rax} 1981$; 36: 605-609.

5. Evain D, Morera AM, Saez JM. Glucocorticoid receptors in interstitial cells of the rat testis. J Steroid Biochem 1976; 7: 1135-1138.

6. Cumming DC, Quigley ME, Yen SSC. Acute suppression of circulating testosterone levels by cortisol in men. $J$ Clin Endocrinol Metab 1983; 57: 671-673.

7. Schaison G, Durand F, Mowszowics I. Effect of glucocorticoids on plasma testosterone. Acta Endocrinol 1978; 89: 126-131.

8. Doerr P, Pirke KM. Cortisol-induced suppression of plasma testosterone in normal adult males. J Clin Endocrinol Metab 1976; 43: 622-629.

9. Nieschlag E, Kley HK. Possibility of adrenal testicular interaction as indicated by plasma androgens in response to hCG in men with normal, suppressed and impaired adrenal function. Horm Metab Res 1975; 7: 326-330.

10. Sakskura M, Takebe K, Nakagawa S. Inhibition of luteinizing hormone secretion induced by synthetic LHRH by long-term treatment with glucocortocoids in human subjects. J Clin Endocrinol Metab 1975; 40: 774-779.

11. Vermeulen A. Clinical review 24: androgens in the aging male. J Clin Endocrinol Metab 1991; 73: 221-224.

12. Nieschlag E, Lammers U, Freischem CW, Langer K, Wickings EJ. Reproductive functions in young fathers and grandfathers. J Clin Endocrinol Metab 1982; 55: 676-681.

13. Gray A, Feldmann HA, McKinlay JB, Longcope C. Age, disease, and changing sex hormone levels in middle aged men: results of the Massachusetts male aging study. $J$ Clin Endocrinol Metab 1991; 73: 1016-1025.

14. Rolf C, Nieschlag E. Senescence. In: Nieschlag E, Behre HM, eds. Andrology: Male Reproductive Health and Dysfunction. Heidelberg, Springer, 1997; pp. 397-399.

15. European Respiratory Society. ERS consensus statement: optimal assessment and management of chronic obstructive pulmonary disease (COPD). Eur Respir J 1995; 8: 1398-1420.

16. Behre HM, Nieschlag E. Testosterone buciclate (20 Aet-1) in hypogonadal men: pharmacocinetics and pharmacodynamics of the new long-acting androgen ester. $J$ Clin Endocrinol Metab 1992; 75: 1204-1210. 
17. American Thoracic Society. Standards for diagnosis and care of patients with chronic obstructive pulmonary disease (COPD) and asthma. Am J Respir Crit Care Med 1995; 152: 77-120.

18. Mahler DA, Harver A, Lentine T, Scott JA, Beck K, Schwartzstein RM. Descriptors of breathlessness in cardiorespiratory diseases. Am J Respirat Crit Care Med 1996; 154: 1357-1363.

19. Wegner RE, Jörres RA, Kirsten DK, Magnussen H. Factor analysis of exercise capacity: dyspnea ratings and lung function in patients with severe COPD. Eur Respir J 1994; 7: 725-729.

20. Kirsten DK, Wegner RE, Jörres RA, Magnussen H. Effects of theophylline withdrawal in severe chronic obstructive pulmonary disease. Chest 1993; 104: 1101-1107.

21. Chandolia RK, Weinbauer GF, Simoni M, Behre HM, Nieschlag E. Comparative aspects of chronic administration of the non-steroidal antiandrogens flutamide and casodex on the reproductive system of adult male rat. Acta Endocrinologia 1991; 125: 547-555.

22. Montanimi V, Simoni M, Chiossi G, et al. Age-related changes in plasma dehydroepiandrosterone sulphate, cortisol, testosterone and free testosterone circadian rhythms in adult men. Horm Res 1988: 29: 1-6.

23. Rommerts FG. Testosterone: an overview on biosynthesis, transport, metabolism and action. In: Nieschlag E, Behre HM, eds. Testosterone-Action, Deficiency, Substitution. Heidelberg, Springer, 1990; pp. 1-22.

24. Decramer M, Lacquet LM, Fagard R, Rogiers P. Corti- costeroids contribute to muscle weakness in chronic airflow obstruction. Am J Respir Crit Care Med 1994; 150: $11-16$.

25. MacAdams MR, White RH, Chipps BE. Reduction of serum testosterone levels during chronic glucocorticoid therapy. Ann Intern Med 1986; 104: 648-651.

26. Semple d'A, Beastall GH, Brown TM, Stirling KW, Watson WS. Sex hormone suppression and sexual impotence in hypoxic pulmonary fibrosis. Thorax 1984; 39: 46-51.

27. Banks WA, Cooper JA. Hypoxia and hypercarbia of chronic lung disease: minimal effects on anterior pituitary function. South Med J 1995; 83: 290-293.

28. Van der Heijden HFM, Dekhuijzen PNR, Folgering H, Van Herwearden CLA. Pharmacotherapy of respiratory muscles in chronic obstructive pulmonary disease. Respir Med 1996; 90: 512-522.

29. Bhasin S, Storer TW, Berman N, et al. The effects of supraphysiologic doses of testosterone on muscle size in normal men. N Engl J Med 1996; 335: 1-7.

30. Schols AMWJ, Soeters PB, Mostert R, Pluymers RJ, Wouters FM. Physiologic effects of nutritional support and anabolic steroid in patients with chronic obstructive pulmonary disease: a placebo-controlled randomized trial. Am J Respir Crit Care Med 1995; 152: 1268-1274.

31. Reid IR, Wattic DJ, Evans MC, Stapleton JP. Testosterone therapy in glucocorticoid-treated men. Arch Intern 1996; 156: 1173-1177. 